Beneš Optát, Petr Gzel, Václav Philomates:

\title{
Gramatika česká.
}

Ed. Ondřej Koupil. Praha: Akropolis 2019. CIV + 134 s.

ISBN 978-80-7470-232-7

Edice tzv. náměštské gramatiky Beneše Optáta, Petra Gzela a Václava Philomatese, která vznikla v Ústavu pro jazyk český AV ČR jako výstup grantového projektu Grantové agentury ČR, je druhou z předpokládaného komplexu edic, které mají zpř́stupnit staročeské mluvnice. O nich se ve výkladech o vývoji češtiny a lingvistického bádání opakovaně mluví, aniž by je měli lingvisté skutečně $\mathrm{k}$ dispozici. Dnes jsou sice $\mathrm{k}$ nahlédnutí v digitalizované podobě dostupné z webových stránek Úč (Vokabulář webový, modul digitalizovaných mluvnic), ale bez poznámkového aparátu a komentářů, které podává edice, je práce s nimi pro možné uživatele - kromě osob v historické mluvnici skutečně zasvěcených - velmi obtížná.

Edice, kterou máme před sebou, má dvě části: výklad o náměštské tiskárně a o textu a jeho tvůrcích, na něž navazuje edice samé památky. Byla vytvořena na základě jediného dochovaného exempláře původní mluvnice, jejího (4.) vydání z r. 1643. Starší podoby textu z let 1533, 1535, 1588 nebyly jako východisko vhodné. Na počátku recenze knihy nacházíme bibliografické údaje, které zaznamenávají všechny studie nebo monografie, které se nějak prezentovaného textu dotýkají; jde o práce až na malé výjimky české, problematika samé mluvnice ani tiskařství na Moravě není tématem světovým.

První z úvodních kapitol je z pera Petra Voita. Je věnována vnější stránce textu tak, jak je k dispozici z r. 1533, tedy prvnímu vydání. Věnuje se písmu, tiskařům a jejich podílu na vydání, tvorbě písmen a jejich užití na pozadí vývoje tiskařských písmen, typografickým zásadám, které se v pěti textech, které v náměštské tiskárně v letech 1533-1535 vznikly, uplatnily. Sleduje i to, do jaké míry mohly být vytvořené typografické zásady (nejde o jazyk, ale o tisk!) šířeji známy; tu bohužel vidíme, že i když byly promyšlené a i z dnešního hlediska moderní, zapadly.

Pro edici vlastní mluvnice má význam část další, která je z pera hlavního editora Ondřeje Koupila. V této části úvozující vlastní edici je výklad koncipován tak, že je obohacující i pro př́jemce, jímž nemusí být nutně filolog zaměřující se na raný novověk. O samých autorech se ví velmi málo a úvodní studie to těžko může doplnit. Autor však v tomto kontextu, jak připomíná Koupil, není podstatný. Nereferuje se o obsahu knihy, ten je jen naznačen, výklad se soustředil na informace nové nebo viděné v nových souvislostech. Poznáváme tu dobový kontext biblických překladů, k nimž se mluvnice přimyká, připomíná se humanistická orientace překladatelů, kteří se nevázali k určité konfesi, i když nacházeli oporu v Erasmově Novém zákoně a jeho „čtení“ a zřejmě znali i jiné (německé) biblické překlady. Už zde můžeme vycítit, že poznání v této věci není a nemůže být, i když zde je množství faktů a odkazů, završeno. Kromě toho si na tomto podkladu uvědomíme, jak bylo vytváření nového biblického překladu, který mohl ovlivnit chápání textu bible i pro další období, tvưrčí činností. A to dávalo podněty pro řešení otázek zvoleného jazyka včetně formy jeho písemného záznamu. 
Úvodní studie počítá s př́jemcem, jímž nemusí být nutně, jak jsme už poznamenali, filolog zabývající se tímto obdobím. Pro možné dnešní čtenáře je však důležité připomenutí, že „česká“ zde znamená lokální určení, nejde tedy o češtinu v dnešním slova smyslu a už vůbec ne o něco, co dnes chápeme jako češtinu spisovnou, a také deklarovaná „gramatika“ není soustavnou mluvnicí v dnešním slova smyslu, ale souborem postřehů. Obsáhlý výklad o jazyku mluvnice, začleněný do studie, je důležitý, a to zejména pro upřesnění představ o inovativním jazyku daných překladů, nebot na rozdíl od zřetelné archaičnosti starších překladů se počítá s jednotlivými prvky jazyka „neprestižního“. Ty se včetně ortografie později uplatnily v bibli zvané „melantriška“ a v překladu Bible kralické, přes niž pak ovlivnily v jednotlivostech psanou češtinu až do našich dní. Vliv daného textu je patrný na už komplexnějších gramatikách češtiny až do 18. století. Přitom tradice poznání jazyka, a to nikoli pouze historické mluvnice, navazují v popisu, jak shledáváme i dnes, na informace těchto starých materiálů někdy až nečekaně. To, že v př́padě naší mluvnice šlo o text důležitý pro nový překlad bible - Bibli kralickou - ukazuje začlenění do Blahoslavovy rukopisné Gramatiky české z r. 1571. Koupil dál tuto linii kromě samého konstatování nesleduje. Zájemce ovšem může přistoupit k porovnání sám, protože Gramatika česká vyšla (i když jinak edičně zpracována než text Koupilův) nově v r. 1991.

Vlastní gramatika, která je dále představena v transliterované podobě, která ctí i užití různých písem v předloze, je opatřena bohatým poznámkovým aparátem, který odkazuje jak na jednotlivé studie, které se věnovaly dílčím tématům, tak vybraným souvislostem dalším. Je ctěno původní rozvržení, které ukazuje titulní list, kde čteme „Gramatika Č̌efka w dwogij ftránce, Orthographia przedkem (...), Etymologia potom (...)“ a kde se upozorňuje př́jemce „Ktožkoli žádáfs čefky rádně čijfti psáti: y z latijny chcefs wykládati máfs tyto z nowa wydané s pilnoftij knijžky přečijfti“. Autoři sami se na titulním listě nejmenují, je však známo, že část první část napsali Optát a Gzel, zatímco část Ethymologia Philomates; ta je na pomezí slovníku a gramatiky v dnešním smyslu, když řeší jednotlivé věci, na něž překladatelé při své práci naráželi včetně rozhodování o vhodnosti, správnosti tvarů slov.

Nemá smysl zde referovat o tom, co konkrétně autoři mluvnice napsali a co je i dnes platné, můžeme jen konstatovat, že je toho více, než bychom očekávali, a to i proto, že netoužili už při překladu bible, kterou zřejmě chápali jako živý text, po petrifikaci archaismů.

Celá edice je prokomponovaná, promyšlená do detailu, a to tak, že metoda může být v budoucnu použita i pro jiné edice odborných textů ze středověku.

Můžeme jen doufat, že edice, jejíž úvodní výklady o textu a jeho tvůrcích jsou jak v češtině, tak v němčině, zpřístupní tuto tematiku nejen další generaci českých, ale i zahraničních bohemistů. 


\section{Marie Krčmová}

Department of Linguistics and Baltic Languages

N

Faculty of Arts, Masaryk University

Arna Nováka 1, 602 oo Brno

Czech Republic

krcmova@phil.muni.cz

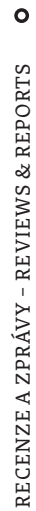

Toto dílo lze užít v souladu s licenčními podmínkami Creative Commons BY-NC-ND 4.0 Internationa (https://creativecommons.org/licenses/by-nc-nd/4.o/legalcode). Uvedené se nevztahuje na díla či prvky (např. obrazovou či fotografickou dokumentaci), které jsou v díle užity na základě smluvní licence nebo výjimky či omezení příslušných práv. 